\title{
Fair Value Accounting vs. Historical Cost Accounting
}

Paul Jaijairam, Bronx Community College, City University of New York, USA

\begin{abstract}
This paper reviews fair value accounting method relative to historical cost accounting. Although both methods are widely used by entities in computing their income and financial positions, there is controversy over superiority. Historical cost accounting reports assets and liabilities at the initial price they were exchanged for at the time of the transaction. Conversely, fair value accounting quotes the prevailing price in the market. Nevertheless, while both methods of accounting affect financial statements, the impact of fair value accounting on the balance sheet and income statement is extreme due to the potential volatility of the method. Fair value accounting is deemed superior when compared to historical cost accounting because it reflects the current situation in the market whereas the later is based on the past. In addition, in relative terms, fair value accounting provides users with more current financial information and visibility.
\end{abstract}

Keywords: Fair Value Accounting and Historical Cost Accounting

\section{INTRODUCTION}

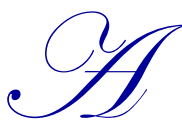

n increasing number of international standards are allowing or requiring the use of fair value accounting for financial reporting purposes. The International Accounting Standards Board (IASB) and Financial Accounting Standards Board (FASB) have agreed to a global uniform framework that establishes a standard definition of fair value that is applicable in ascertaining the worth of assets and liabilities without involving market value. In recent years, there has been substantial controversy over the use of fair value accounting as opposed to the historical cost accounting method. While financial statements are designed to reflect reality, opinions vary as to which method best represents that reality. Because a firm's choice of accounting treatment for various assets can have a significant impact on its financial statements, and management decisions regarding future corporate actions, it is important that the appropriate method be applied. This paper reviews fair value accounting by comparing it with historical cost accounting and the effects it has on financial statements such as the balance sheet, income statement, and the statement of cash flows.

\section{FASB CLARIFICATIONS AND CHANGES}

FASB defines fair value accounting through the declaration of the statement - Financial Accounting Standard No. 157: Fair Value Measurements. FASB describes fair value as the price at which knowledgeable and willing parties will exchange or settle assets or liabilities. Fair value accounting is the practice of declaring the value of the asset or liabilities (Financial Standards Accounting Board [FASB], 2011). Under fair value accounting, a company resets the prices of certain assets on its balance sheet every quarter to reflect changes in the market price; thus, called "mark-to-market accounting". For instance, the firm is supposed to determine the value of its security by considering the exit price. This exit price is considered as the fair value of the security based on the assumption that the transaction took place between willing and knowledgeable participants - the buyer and the seller of the security. However, the use of exit price may fail to reflect the fairness of the asset or liability value especially when one participant is not knowledgeable or willing to transact. For instance, forced liquidations of assets may result in markedly lower prices than ones based on fair value on the expected cash flows of the asset.

The first definition is inappropriate in determining the fair value of an asset or liability. As a result, the FASB and IASB have agreed on a modified method to determine fair value. Instead of basing market price on an 
exit price, the new rules allow companies to look for the most advantageous market for an asset or liability when assigning it a fair market value. Determining the true market value of an asset is sometimes controversial, especially for assets that do not have active and liquid markets. By definition, the fair value does not need the existence of an active market. In case of market inexistence, IASB offers guideline that looks at the type of assets or liabilities. For instance, for property, plant and equipment, depreciated replacement cost is recommended if market based evidence is unascertainable. For biological assets (animals and plants), IASB suggest the use of discounted present values of future cash flows (Weetman, 2011).

Later, FASB introduced FASB ASC 820 - Fair Value Measurements and Disclosures (SFAS 157) (Zyla, 2010). The main aim of this statement is to offer additional guidance and information on issues that relate to fair value and its measurement. FASB ASC 820 - Fair Value Measurements, in technical terms, does not bring in any new accounting principle rather it provides financial analysts and auditors with "additional information on how the FASB intends fair value to be measure in any instance it is required in financial reporting" (Zyla, 2010). The FAS 159 - the Fair Value Option(FVO) on Financial Assets and Financial Liabilities - brings in the fair value option that a company may use in their first and successive measurements of their particular financial liabilities and assets on contract basis (American Academy of Actuaries Life Financial Reporting Committee [AAALFRC], 2009). The changes of fair value recorded in this contract basis are reported in the earnings. FAS 159 improves financial reporting by reducing volatility in reported earnings that originate from related financial assets and liabilities without incorporation of complex accounting provisions. Some of the notable financial assets and liabilities include insurance contracts, leases, convertible debt security, deposit liabilities, credit union, subsidiary investment, employment (pre- and post-) benefits and entities with variable interests. The disclosures made through FAS 159 must incorporate the main reason for choosing this option, additional information for items in the balance sheet and the value of gains or losses quoted in the income statement as well as in the balance sheet (AAALFRC, 2009).

\section{FAIR VALUE VS. HISTORICAL COST ACCOUNTING}

Fair value accounting is an improvement to the traditional form of accounting - the historical cost accounting. Under historical cost accounting, the initial price paid by the company during the purchase of the asset or incurrence of the liability is the one that matters. The price reflected on the balance sheet either is the purchase price or at a value reduced by obsolescence, depreciation or depletion (Nobes, 1997). For a financial asset, the price on the balance sheet does not change until the security is liquidated. Historical cost accounting is easy to understand because it is based on a fixed price that is always completely known, specifically the actual price that a company paid. Historical cost accounting is generally easier to follow since it is based on fixed and certain inputs. While this eliminates uncertainty from the initial valuation decision, it creates uncertainty in future periods about the true value of assets (Meunier, 2012). In both fair value accounting and historical cost accounting methods, the value of assets depicted on the balance sheet is always lower due to the depreciation, depletion and obsolescence.

In the financial industry, for example, certain assets, such as securities that have been labeled "trading securities" or "available-for-sale securities" may either appreciate or depreciate according to market movements and have always been subject to market-based pricing. However, the values can only decline for securities labeled as "held-to-maturity securities". In addition, these debt securities are reported as an amortized form rather than depreciation (Stickney, Well, Schipper \& Francis, 2006). Such securities include bonds and leases. Accounting rules require firms to determine if certain assets, such as goodwill, have been impaired. If the value of an "impairable" asset falls and is not expected to recover, the firm must record a charge for other-than-temporary impairment (OTTI) which lowers the value of the asset on the balance sheet. This OTTI charge is permanent and cannot be reversed even if the asset eventually recovers its market value (Goldman Sachs Asset Management, 2008). However, the firm would still be able to benefit from the recovery in value by either collecting the cash flows from the asset or selling the asset at the higher price and realizing a capital gain.

Generally, it is anticipated that when an entity bases its financial statements on fair value accounting method, the value or amounts will fluctuate from time to time compared to when historical cost accounting is used. The value of items that are accounted for using historical cost method change at a lower rate, thus, it is considered less volatile. In fair value accounting, the recognized values change from time to time, hence, higher volatility. This volatility emanates because this accounting method summarizes "the stream of expected future cash flows: a change 
in expectation relating to any of the cash flow changes in the fair value" (Barth, 2004). The volatility within the financial statements does not imply that there is a flaw in financial reporting rather it is one that is always anticipated. The proponents of fair value accounting consider the historical cost accounting less volatile not because it is superior but because it provides a company's results that are not based on possible subjective appraisals or some other valuation methods.

\section{EFFECTS ON BALANCE SHEET}

Under FAS 159, the choice of accounting treatment for recording certain financial assets, which do not required adherence to specific fair value accounting rules, can result in a dramatic impact on the balance sheet, especially for companies with large investment portfolios such as insurance or bank holding companies. In amortized cost, financial securities held up to maturity and notably debt securities are always carried on the balance sheet at the acquisition price paid by the entity. Thus, from one quarter to another there will be no volatility in the prices of individual securities. On the other hand, with fair value accounting, the price of debt security is adjusted with accordance to the market price at a given time. Such gyrations noted in fair value accounting would have significant impact on the daily operation of the business.

Since a balance sheet is a measure of a company's financial position, it is a crucial financial document to any business entity. For instance, the law requires financial institutions (banks) and insurance companies to maintain certain level of equity - usually portrayed on the balance sheet (Zyla, 2010). Standard accounting defines equity as the difference between assets and liabilities. Thus, as these two figures vary, equity also varies - increases or decreases. Because banks rely on leverage ratio, a small variation in the value of their assets will have a greater impact on their size of equity. For example, during the 2008-2010 economic meltdown, there were financial crisis that led to the decline of asset values (Zyla, 2010). In turn, as the value of assets declined, the equity of banks declined. The position of many banks as shown on the balance sheets deteriorated. This situation called for financial institutions to raise more equity in order to bring their balance sheet back to position required by government regulations.

In the non-financial sector such as manufacturing, wholesale and retail industries, the balance sheet values are less important compared to financial sector but they still have a real impact. Investors and creditors rely on the value of assets in determining the credit worth of an entity - lenders consider the value of assets as collateral while investors consider the value of asset as the indication of the entity's operation status now and probably in future (Zyla, 2010). The decline of assets will cause problems within the entity; for instance, the company will not be able to service its loans and at the same time, it will not attract investors because of pessimism resulting from that decline. In summary, fair value accounting will have effects on balance sheets of entities; however, financial institutions are likely to be more affected than non-financial sector.

\section{EFFECTS ON INCOME STATEMENT}

Fair Value Option (FVO) election choice may have a substantial effect on income statement and earnings. Whilst certain changes in values are only reflected on the balance sheet, OTTI (Other-Than-Temporary Impairment) changes that flow through income statement have a direct impact on net income; for instance, the value of available for sale securities. FAS 115, states categorically that trading assets are held with an aim of disposing them in the near future (Laux \& Leuz, (2010). Securities like bonds and treasury bills are marketable securities thus they are reported at fair value whereby the changes noted are recognized in the income statement. Thus, considering OTTI charges, some negative but significant impacts on earnings may emanate from this rule. Therefore, many firms are hesitant to take these charges unless regulators or auditors force them. According to FAS 157, the OTTI for both market movements and credit impairments are required. However, the 2009 amendments required OTTI charges on credit impairments only.

FASB considers any security - bond or treasury - with a book value that is greater than market value as impaired. After OTTI occurs, the gross loss recorded is equal to the difference between the book value and the fair value (Deutsche Bank Group, 2009). This difference is recorded in the income statement as a reduction of the earnings. In the book value entry, the change is recorded as a decline of the security value. Changes in value due to 
market movements no longer flow through the income statement but are still reflected in the amounts carried on the balance sheet. Fair value accounting is now more aligned with the existing accounting treatment for individual loans. For individual loans, credit impairments result in income statement charges; however, they do not result from the shifts of interest rates.

\section{EFFECTS ON CASH FLOW STATEMENT}

Unlike the balance sheet and income statement, the use of fair value accounting does not have a direct impact on the statement of cash flows of an entity. The entities will eliminate any OTTI charge that applies under fair value accounting back into their income statements as part of operating cash flow. In securities, FASB defines credit loss as specific changes in the cash flow; that is, if bond quality declines (say from AA to A-), the resulting decline in market value does not constitute a credit loss, unless if the expected amount to be received is less compared to the contractual amount of the cash flow (Deutsche Bank Group, 2009). Thus, the statement of cash flows only reflects the interest payments, dividends, and realized gains from selling securities that are already included in net income. The change to the statement of cash flows is indirect in that the net income figure will be different, creating a cosmetic difference between the two methods. When using fair value accounting, the cash flow statement will most likely start with a lower net income figure; then, OTTI charges are added later. However, the net results shown by the statement of cash flows of either methods - historical cost and fair value accounting are generally similar.

The statement of cash flows is however affected by taxes. Tax rules add a layer of complexity to arriving at the level of OTTI, since the Internal Revenue Service (IRS) does not view all impairments equally. For publicly traded securities, the IRS does not allow an OTTI deduction to be taxable income. The appropriate reduction in taxes will occur when that loss is realized, usually by selling the security in question (Moran, 2010). For a bank taking an OTTI charge on a loan that is likely to default, the IRS does allow an immediate tax deduction. Essentially, the IRS makes a distinction between credit losses, which are deductible, and unrealized market losses, which are not deductible. In some instances, accountants may be able to argue that a portion of the loss on a security is attributable to credit losses and a portion is attributable to market losses. If a company does qualify for a deduction, cash taxes will be lower using fair value accounting rather than historical cost accounting, leading to higher operating cash flow under the fair value method (Moran, 2010). This tangible improvement in cash flow through lower tax payments is just one advantage of fair value accounting. This situation implies that the company with higher cash flows generally compiles higher valuations.

\section{MANIPULATION OF FINANCIAL STATEMENTS}

Both the historical cost and fair value accounting methods have some faults in that entities may use them to manipulate their financial positions and results. For instance, a firm using historical cost accounting method may manipulate its figures on depreciation in order to increase or overestimate the useful life of an asset or its residual value. In that case, the firm will overestimate its income. Entities use this shrewd way of inflating income to attract investors and creditors by deceiving them about the profitability and financial position of the business (Belinna, Yen \& Yang, 2008). Using historical cost accounting, the management teams have more leeway to hide bad investment decisions and avoid the consequences of declining levels of equity and assets. Thus, it is unlikely for any entity to disclose its financial failure through historical cost accounting method.

Using fair value accounting, entities can still manipulate their financial statements, however, in different ways. For instance, the management team can decide to take large OTTI charge in a single quarter. This action implies that the entity's asset value is underestimated. Thus, in such situation, the entity will benefit from higher earnings in subsequent periods, as cash flows are stronger than what the values carried on the balance sheet would suggest. To investors who consider returns on equity, the financial statements of such a company will look promising because the equity is low (as manipulated) compared to its returns (Belinna, et al., 2008). Using fair value accounting, the entity incurs a loss before enjoying future subsequent benefits. However, in historical cost accounting, the benefits to the firm comes first then loss thereafter. Therefore, in either method used by an entity, the investors and creditors are likely to suffer from these manipulations. 
Regardless of the accounting method a firm chooses, ethical dilemmas are likely to occur among executive management. Corporate executives who are usually incentivized with regard to the financial performance of the entity are likely to deploy any means, even manipulation, in order to attain their goals (Belinna et al., 2008). For instance, an executive who earns extra incentive based on net income may want to delay taking OTTI charges for fear of losing a bonus. Conversely, an executive whose key metric is return on equity may want to accelerate charges. Based on such dilemmas, it is quite challenging because the accounting decision undertaken by any entity is relatively subjected to the underlying interests of its top management.

\section{OBJECTIONS TO FAIR VALUE ACCOUNTING}

Many entities are still opposing fair value accounting because of its pro-cyclicality and other associated flaws in the mark to market. As the economic cycle falls, asset prices also fall, depressing earnings for companies more than under the historical cost method. This leads to raising capital when company valuations are low, further compounding the problems for a company. In fair value accounting, it is very difficult to ascertain the exact fair value of an asset or liability (American Bankers Association, 2011). For instance, in a situation where a secondary market of an asset does not exist, it is very difficult to replace such an asset with an identical one. Thus, the determination of fair value of that asset is then up to the prudence of the executive. For assets without market prices, fair value accounting relies on appraisals and the calculations of reproduction costs as well as index numbers. However, these methods are based on discretions of management. Thus, fair value accounting is a subjective method of accounting; hence, the termed fairness may not imply fair value because of subjectivity.

During the financial crisis of 2008, many financial firms cited the switch to fair value accounting as a cause of their problems (Laux \& Leuz, 2010). For instance, during the crisis the shares of Barrick Gold Corporation $(\mathrm{ABX})$ declined at a higher rate. Researchers attributed the fall to the market illiquidity and increased risk aversion because of volatility in reporting its financial position and income. For instance, The American Bankers' Association (ABA) objected to the standard because of its use of exit pricing, OTTI charges for market movements, the inability to recover OTTI charges and the use of fair value pricing for all financial instruments (American Bankers Association, 2011). Due to some faults, FASB and IASB have made some changes on their rules. For instance, they only require OTTI charges on credit impairments. Therefore, an entity that holds a security with a market value higher than its balance sheet value can already sell the asset to realize that appreciation or simply hold the asset and later enjoy the better-than-forecasted cash flows.

\section{FINAL THOUGHTS AND CONCLUSION}

Choosing the appropriate accounting method can be difficult, as there are advantages and disadvantages to each. This article has reviewed fair value accounting method in comparison with historical cost accounting. Historical cost method is considered easy to use and simple to understand. However, the proponents of fair value accounting consider historical cost accounting as obsolete because of flaws such as it focuses on cost allocations rather than in the value of an asset and during times of significant inflation, the prices for an asset remains unchanged. According to many, historical cost accounting does not reflect reality or the current market situation. Fair value accounting on the other hand quotes the current value of assets and liability as per the market conditions. In fair value accounting, FASB and IASB have given guidelines on how assets and liabilities should be valued. For instance, statement FAS 157 calls for assets and liabilities to be valued using the market price. Moreover, FAS 159 calls for entities to measure the value of assets and liabilities on contractual basis. Like historical cost, fair value accounting affects the financial statements - balance sheet and income statement. However, there is no direct impact towards the statement of cash flows unless there is a tax benefit granted when using fair value accounting (Moran, 2010). Fair value accounting has some flaws like subjectivity and complexity. However, the IASB and FASB have worked out a common resolution on these issues. Finally, comparing the number of issues and its advantages, fair value accounting is superior compared to historical cost accounting.

\section{AUTHOR INFORMATION}

Paul Jaijairam, CPA is an assistant professor and financial accounting coordinator in the Department of Business and Information Systems at Bronx Community College (CUNY). He has been part of the faculty at Bronx 
Community College for 20 years. His teaching specialties includes: financial and intermediate accounting. He has 20 years of diversified work experience in Audit, Financial and Management Accounting which includes working for companies such as Citigroup (Director) in New York and Prudential Insurance Company (Auditor) in New Jersey. He received a BS in Accounting from Herbert H. Lehman College (CUNY) in 1991 and a MBA in Finance from Manhattan College in 1997. He is an active member in the American Institute of Certified Public Accountant and the National Business Education Association. His publication on "Engaging Accounting Students: How to Teach Principles of Accounting in Creative and Exciting Ways" can be found in the American Journal of Business Education (January 2012). His research interest is diversified in the following areas: accounting, economics, and public policy. E-mail: paul.jaijairam@bcc.cuny.edu

\section{REFERENCES}

1. American Academy of Actuaries Life Financial Reporting Committee. (2009). FAS 157 and FAS 159. Washington DC: American Academy of Actuaries

2. American Bankers Association. (2011). Fair value and mark to market accounting. Retrieved from http://www.aba.com/issues/issues fairvalue.htm

3. Barth M. E. (2004). Fair values and financial statement volatility. In, Borio, C., Hunter, W. C., Kaufman, G. \& Tsatsaronis, K. (Eds.), Market Disciplines across Countries and Industries (323-333). Cambridge, MA: the MIT Press.

4. $\quad$ Belinna, B., Yen, J. \& Yang, X. (2008). False financial statements: characteristics of china's listed companies and cart detecting approach. International Journal of Information and Technology \& Decision Making 7(2), 339-359

5. Deutsche Bank Group. (August 2009). US GAAP impairment accounting: understanding FASB staff position 115-2, http://www.insuranceam.db.com/insurance/EN/_media/Understanding_FASB_115-2.pdf

6. Financial Standards Accounting Board (FASB) (2011), Summary of statement No. 157: Fair Value Measurements. Retrieved from www.fasb.org/summary/stsum157.shtml

7. Goldman Sachs Asset Management. (2008). The Meaning of Other-than-Temporary Impairment (OTTI): Latest Developments and Best Practices. Retrieved from http://www.goldmansachs.com/gsam/pdfs/USI/clients/otti.pdf

8. Laux, C. \& Leuz, C. (2010). Did fair-value accounting contribute to the financial crisis? Journal of Economic Perspectives, 1-41

9. Meunier, K. (2012). Historical cost and fair value accounting. Retrieved from http://business-accountingguides.com/historical-cost/

10. Moran, P. (August 2010). Deducting OTTI adjustments. Retrieved from http://www.plantemoran.com/perspectives/articles/Pages/deducting-otti-adjustments.aspx

11. Nobes, C. (1997). Introduction to financial accounting. Berkshire House: George Allen \& Unwin.

12. Stickney, C. P., Well, R. L., Schipper, C. \& Francis, J. (2006). Financial Accounting: An Introduction to Concepts, Methods, and Uses. Natorp Boulevard Mason, OH: South-Western Cengage Learning.

13. Weetman, P. (2011) Financial and management accounting: An introduction 4th Ed. London: Financial Times Prentice Hall

14. Zyla, M. L. (2010). Fair value measurements: Practical guidance and implementation. Hoboken, New Jersey: John Wiley \& Sons 